\title{
企業と家計の相互作用を考慮した始業·出発時刻均衡モデル* A Simultaneous Equilibrium Model of Work Start Time \& Departure Time Choices with Bottleneck Congestion *
}

\author{
佐藤慎太郎**・赤松隆*** \\ By Shintaro SATO** and Takashi AKAMATSU***
}

\section{1. はじめに}

毎朝, $\mathrm{CBD}$ 一向かう道路では，慢性的な交通渋 滞が発生している。この要因は，時間的に集中する 発生交通量に対して，ボトルネック容量が制限され ている点にある。しかし，TDM の観点から考えれ ば, この交通渋滞の根本的な要因は, 企業の定める 始業時刻が集中している点にあるといえる。このこ とから従来，TDMの一環として，企業の始業時刻 を分散させる施策について議論がなされてきた。

家計（通勤者）の立場からは，交通渋滞による時 間損失等の費用負担を軽減することができるので， 始業時刻を分散させることは望ましい。この家計の みの通勤行動を扱った既存研究としては, C.Hendrickson')がある。一方，企業の立場では，始 業時刻が分散すると，企業間の相互取引機会が減少 し，生産性が低下寸るので，始業時刻の分散は望ま しくない.このことは企業の始業時刻選択問題を扱 つた J.V.Henderson ${ }^{2}$ や文 ${ }^{3)}$ ，鉄道通勤を対象とした 奥村・小林・田中 ${ }^{4)}$ の既存研究においても指摘され ている。このように，始業時刻の分散を推進する TDM 施策は, 社会的には家計の通勤混雑解消と, 企業の生産性低下のトレードオフ関係を内包してい ることがわかる．ゆえに，よりマクロな視点で，企 業間の始業時刻集積とボトルネック混雑の社会的是 非を議論するためには，企業と家計双方の行動を合 わせて考える必要がある。

本稿では，企業の始業時刻選択と，ボトルネック混雑 を考慮した家計の始業・出発時刻選択の両方を内生化し たモデルを構築し，その均衡パターンを解析する．その 上で，社会的に望ましい時刻選択パターンはどのような 均衡パターンであるかを明らかにする，その結果から，現 実問題との対応を考慮しつつ，効果的な通勤混雑緩和施 策について検討する.

*キーワーズ : TDM, 発生交通量, ボトルネック混雑 **学生員, 東北大学大学院情報科学研究科

（率980-8579 仙台市青葉区荒巻青葉6-6

TEL022-795-7507, FAX022-795-7505)

***正会員, 工博, 東北大学大学院情報科学研究科

（干980-8579 仙台市青葉区荒巻青葉6-6

TEL022-795-7507, FAX022-795-7505)

\section{2. モデルの定式化}

\section{(1) 都市と交通条件の設定}

本モデルでは，毎朝総数 $N$ の通勤者が住宅地区 から CBD へ自動車で通勤する都市を想定する.

図 1 に示すように，彼/彼女らのトリップは単一 OD であり, 唯一のボトルネックを通過する.この ボトルネックには, 物理的な渋滞長を考慮しない point queue モデルを仮定する.ここで，通勤者は毎 朝通勤行動を繰り返すことで，経験的に住宅の出発 時刻とボトルネックの到着・出発時刻の関係を把握 できる．このことから，各通勤者はボトルネック出 発時刻 $t_{d}$ を選択することで, 間接的に住宅の出発時 刻とボトルネック到着時刻 $t_{a}$, 待ち行列時間も選択 していると考える.

この通勤行動で，通勤者が消費する時間は，ボト ルネックでの待ち行列時間 $q$ と, $\mathrm{CBD}$ 到着時刻か ら始業時刻までの空き時間であるスケジュール時間 $s=\left|t_{w}-t_{d}\right|$ のみと仮定する.このとき,通勤者が経験 する通勤費用は，これらの通勤時間をそれぞれ機会 費用として金額に換算した待ち行列費用 $C_{Q}(q)$ と, スケジュール費用 $C_{S}(s)$ である. $C_{Q}(q)$ は $q$ に対して 線形, $C_{S}(s)$ は $s$ に対して 2 次関数と定義する（付録 1 参照)

$$
\begin{gathered}
C_{Q}\left(q\left(t_{d}\right)\right) \equiv q\left(t_{d}\right) \\
C_{S}\left(t_{d}, t_{w}\right) \equiv \beta \cdot\left|t_{w}-t_{d}\right|^{2}
\end{gathered}
$$

ここで， $\beta$ はスケジュール時間に対する時間価値パ ラメータであり, その時間価値は待ち行列時間 $q$ を 正規化したものとする.

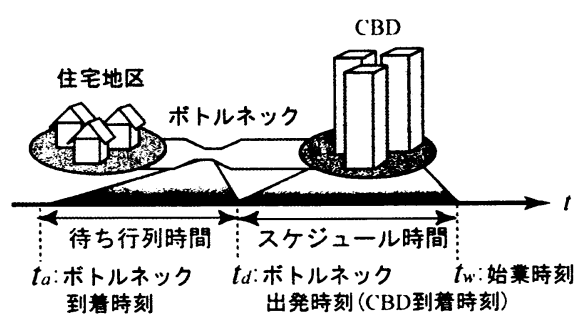

図一 1 都市空間と時間軸の関係 


\section{（2）各主体の行動}

本稿で構築するモデルに登場する主体は, 同質な 総数Nの家計と, 一企業あたりLの家計を雇用する 総数Mの企業である．以降では，混乱のない限り， 一家計=一労働者二一通勤者として議論をすすめる. 各主体の行動は以下のように表される.

\section{a) 企業の行動}

企業は, 自らの利潤を最大にするように始業時刻 $t_{w}$ を選択する.ここで, 企業の生産性には, 企業間 での相互取引による正の外部性が発生し，これは始 業時刻 $t_{w}$ の選択によって異なる. 寸なわち, この 外部性は業務を行っている企業間でのみ作用するた め, 始業時刻 $t_{w}$ を選択した企業の生産性は， $t_{w}$ でよ り多くの企業が始業しているほど高くなる。ここに 企業の生産性についての始業時刻集積の経済が発生 する. また, 生産要素投入量に対する生産額は $k$ で 一定とみなす。これらの仮定から, 始業時刻集積の 効果を考慮した企業の生産関数 $F\left(t_{w}\right)$ を次式のよう に定義する：

$$
F\left(t_{w}\right) \equiv k\left(\int_{t_{0}}^{t_{w}} m(\omega) d \omega+\int_{t_{w}}^{T}\left\{1-\alpha \cdot\left(\omega-t_{w}\right)\right\} \cdot m(\omega) d \omega\right)
$$

式(3)で, $m(\omega)$ は始業時刻 $\omega$ の企業数, $t_{0}$ は最初に 始業する企業の始業時刻, $T$ は最後に始業する企業 の始業時刻である. 第 1 項は始業時刻 $t_{w}$ で既に始 業している企業から作用する正の外部性であり, 第 2 項は $t_{w}$ より後から始業する企業から作用する外部 性である. すなわち, 始業時刻 $t_{w}$ を選択する企業 に対して， $t_{w}$ より後から始業する企業からの外部性 は, 各々の始業時間差について $\alpha$ の割合で線形に隇 衰する.

この式(3)で与えられる生産性の条件下で, 各企 業は利潤 $\pi$ を最大化するように始業時刻 $t_{w}$ を選択 する.

$$
\max _{t_{w}} \pi\left(t_{w}\right)=\max _{t_{w}}\left[F\left(t_{w}\right)-W^{*}\left(t_{w}\right) \cdot L\right]
$$

式(4)で, $W\left(t_{w}\right)$ は始業時刻選択 $t_{w}$ を選択する企業の 労㗢者（家計）への支払い賃金， $L$ は一企業あたり の雇用者数である.

\section{b) 家計の行動}

式(1),(2)で与えられる待ち行列費用とスケジュー ル費用の条件下で, 各家計は次のような 2 段階の時 刻選択行動を行う。 まず, 効用 $z$ を最大化するよう に, 就職先企業, 寸なわち始業時刻 $t_{w}$ を選択し, 次に総通勤費用 $C_{T}\left(t_{d}, t_{w}\right)$ を最小化するようにボト ルネック到着時刻 $t_{d}$ を選択する。この選択の際に, 各家計は待ち行列時間 $q$ を考慮してボトルネック出 発時刻 $t_{d}$ を選択するので，ボトルネック到着時刻 $t_{a}$ も同時に選択していることになる.ここで，家計 の効用関数は, 合成財消費量に対して準線形な効用 関数と定義すると, 家計の 2 段階の選択行動は以下 の式で定式化される：

$$
\max _{t_{w}} z\left(t_{w}\right)=\max _{t_{w}}\left[W\left(t_{w}\right)-C_{T}\left(t_{w}\right)\right]
$$

$$
\min _{t_{d}} C_{T}\left(t_{d}, t_{w}\right)=\min _{t_{d}}\left[C_{Q}\left\{q\left(t_{d}\right)\right\}+C_{S}\left\{s\left(t_{d}, t_{w}\right)\right\}\right]
$$

\section{（3）均衡条件の定式化}

本モデルにおける均衡状態とは，企業と家計が選 択する始業時刻と, 家計の選択するボトルネック出 発時刻が同時に均衡する状態である.この状態では, 家計の均衡効用とボトルネック出発家計数, 待ち行 列時間, ボトルネック到着家計数が全て内生的に定 まる. そこで, 本節では，この均衡状態を決定する ための条件を定式化する.

\section{a）企業の始業時刻選択についての均衡条件}

均衡状態では, どの企業も始業時刻 $t_{w}$ を変更し ても，利潤を増加させることができない，従って， 時刻 $t_{w}$ に始業する企業が存在する場合には, その 企業の利潤は完全競争下での均衡利潤 $\pi^{*}=0$ に等し く, 始業する企業が存在しない場合は, その時刻に おける利潤は $\pi^{*}$ 以下である :

$$
\left\{\begin{array}{l}
F\left(t_{w}\right)-W^{*}\left(t_{w}\right) L=\pi^{*}=0 \quad \text { if } \quad m\left(t_{w}\right)>0 \\
F\left(t_{w}\right)-W^{*}\left(t_{w}\right) \cdot L \leq \pi^{*}=0 \text { if } \quad m\left(t_{w}\right)=0
\end{array} \forall t_{w}\right.
$$

ここで, $m\left(t_{w}\right)$ は始業時刻 $t_{w}$ を選択する企業数であ る.

\section{b）家計の始業時刻選択についての均衡条件}

均衡状態では, どの家計も始業時刻 $t_{w}$ を変更し てもその効用を増加させることができない，すなわ ち, 時刻 $\boldsymbol{t}_{w}$ を始業時刻に選択する家計が存在する ならば，その家計の得る効用は均衡効用 $z^{*}$ に等しく， 選択する家計が存在しないならば，その時刻で得ら れる効用は $z^{*}$ 以下である：

$$
\left\{\begin{array}{l}
W\left(t_{w}\right)-C_{T}^{*}\left(t_{w}\right)=z^{*} \text { if } \int n\left(t_{d}, t_{w}\right) d t_{d}>0 \\
W\left(t_{w}\right)-C_{T}^{*}\left(t_{w}\right) \leq z^{*} \text { if } \int n\left(t_{d}, t_{w}\right) d t_{d}=0
\end{array} \forall t_{w}\right.
$$

ここで, $n\left(t_{d}, t_{w}\right)$ はボトルネック出発時刻 $t_{d}$, 始業時 刻 $t_{w}$ を選択する家計数である.

\section{c）家計の出発時刻選択についての均衡条件}

均衡状態では, どの家計もボトルネック出発時刻 $t_{d}$ を変更しもその通勤費用を減少させることがない. 従って, 時刻 $t_{d}$ と $t_{w}$ をそれぞれ出発時刻, 始業時 刻に選択した家計が存在する場合には，その家計の 経験するスケジュール費用と待ち行列費用の和は, 均衡通勤費用 $C_{T}^{*}\left(t_{W}\right)$ に等しく, これらの時刻の組合 
せを選択する家計が存在しない場合には，その費用 の和は $C_{T}^{*}\left(t_{w}\right)$ より大きくなっている :

$$
\left\{\begin{array}{l}
C_{Q}^{*}\left(t_{d}\right)+C_{S}^{*}\left(t_{d}, t_{w}\right)=C_{T}^{*}\left(t_{w}\right) \text { if } n\left(t_{d}, t_{w}\right)>0 \\
C_{Q}^{*}\left(t_{d}\right)+C_{S}^{*}\left(t_{d}, t_{w}\right) \geq C_{T}^{*}\left(t_{w}\right) \text { if } n\left(t_{d}, t_{w}\right)=0
\end{array} \forall t_{w}, t_{d} .\right.
$$

\section{d）労働市場での需給均衡条件}

正の貨金が成立する始業時刻 $t_{w}$ では，労働需給 が一致しており, 賃金が成立しない時刻では, 労働 需給は一致していない：

$$
\left\{\begin{array}{l}
m\left(t_{w}\right) \cdot L-\int n\left(t_{d}, t_{w}\right) d t_{d}=0 \text { if } W\left(t_{w}\right)>0 \\
m\left(t_{w}\right) \cdot L-\int n\left(t_{d}, t_{w}\right) d t_{d} \leq 0 \text { if } W\left(t_{w}\right)=0
\end{array} \forall t_{w} .\right.
$$

\section{e）ボトルネック容量の条件}

䠈滞によって, 待ち行列費用が発生する時刻 $t_{d}$ で は, ボトルネック出発家計数はボトルネック容量 $\mu$ に等しく, 橴滞が発生しない時刻では, 出発家計数 はボトルネック容量以下である：

$$
\left\{\begin{array}{l}
\mu-\int n\left(t_{d}, t_{w}\right) d t_{w}=0 \text { if } C_{Q}\left(t_{d}\right)>0 \\
\mu-\int n\left(t_{d}, t_{w}\right) d t_{w} \geq 0 \text { if } C_{Q}\left(t_{d}\right)=0
\end{array} \forall t_{d} .\right.
$$

\section{f）主体数の保存条件}

本モデルでは企業の雇用者数と家計数について, 閉じた都市を考えているので, 企業数 $m\left(t_{w}\right)$ と家計 数 $n\left(t_{d}, t_{w}\right)$ の総和はそれぞれ総企業数 $M$ と総家計数 $N$ に等しい.

$$
\begin{aligned}
& \int m\left(t_{w}\right) d t_{w}=M=N / L \\
& \iint n\left(t_{d}, t_{w}\right) d t_{w} d t_{d}=N
\end{aligned}
$$

以上で定式化した均衡状態下での家計のボトルネ ック到着・出発時刻選択パターンを求めるために は, ボトルネックでの待ち行列に関する “物理的条 件”を考慮する必要がある。 その “物理的条件” は, 次の 2 つの条件である. 1 つは, ボトルネック 到着時刻 $t_{a}$ における待ち行列長 $Q\left(t_{a}\right)$ が, 時刻 $t_{a}$ ま での累積到着者数 $A\left(t_{a}\right)$ と時刻 $t_{a}$ までの累積出発者 数 $D\left(t_{a}\right)$ の差で与えられること :

$$
Q\left(t_{a}\right)=A\left(t_{a}\right)-D\left(t_{a}\right)
$$

である.もう 1 つは, 待ち行列時間と待ち行列長の 関係に関する条件 :

$$
q\left(t_{d}\right)=Q\left(t_{a}\left(t_{d}\right)\right) / \mu
$$

である.すなわち, 時刻 $t_{d}$ にボトルネックを出発す る家計が経験する待ち行列時間 $q\left(t_{d}\right)$ は, 到着時刻 $t_{a}$ に発生する待ち行列長 $Q\left(t_{a}\left(t_{d}\right)\right)$ を単位時間当り容 量 $\mu$ で別くのに必要な時間である。ここで, 時刻 $t_{a}\left(t_{d}\right)$ は, 時刻 $t_{d}$ にボトルネックを出発した家計

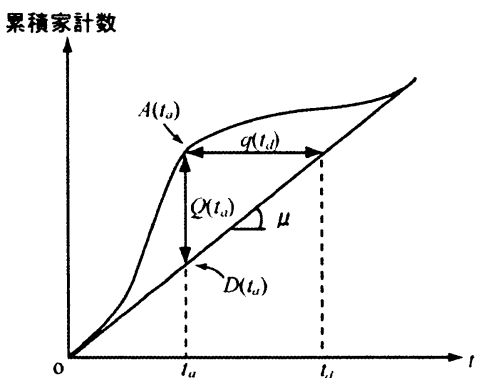

図ー2 ボトルネック待ち行列の物理的条件

が，ボトルネックに到着した時刻である.

均衡条件式(7)-(13)で決まる均衡状態下で, ボ卜 ルネックの物理的関係式 (14), (15) と整合的な待ち 行列時間, 累積到着家計数, 到着者数を求める手順 を示す．まず，本モデルのような単一ボトルネック の問題では, 均衡条件(9),(11),(12)のみから, 均衡待 ち行列費用 $q^{*}\left(t_{d}\right)$ を決定できる（その証明は， $\mathrm{Smith}^{5)}$, 井料 ${ }^{6)}$ を参照). 次に, その均衡待ち 行列費用から, 時刻 $t_{d}$ にボトルネックを出発する家 計が経験する均衡待ち行列費用 $q^{*}\left(t_{d}\right)$ を時間に換算 して均衡待ち行列時間 $q^{*}\left(t_{d}\right)$ を求める. この均衡待 ち行列時間 $q^{*}\left(t_{d}\right)$ を用いれば, 出発時刻 $t_{d}$ に対応す る到着時刻 $t_{a}$ が定まる：

$$
t_{a}\left(t_{d}\right)=t_{d}-q^{*}\left(t_{d}\right) .
$$

さらに, 式(15)の条件から, 到着時刻 $t_{a}\left(t_{d}\right)$ におけ る待ち行列長 $Q\left(t_{a}\left(t_{d}\right)\right)$ が定まる. この $Q\left(t_{a}\left(t_{d}\right)\right)$ と, 均衡条件から求まった到着時刻 $t_{a}\left(t_{d}\right)$ までの均衡累 積出発家計数 $D\left(t_{a}\left(t_{d}\right)\right)$ を式(14) に代人すれば, 到 着時刻 $t_{a}\left(t_{d}\right)$ における均衡累積出発家計 $A\left(t_{a}\left(t_{d}\right)\right)$ が 得られる.この計算を各時刻 $t_{d}$ について繰り返せ ば, 各到着時刻 $t_{a}\left(t_{d}\right)$ に対応した累積到着家計数 $A\left(t_{a}\left(t_{d}\right)\right)$ が求められる. また, $t_{a}\left(t_{d}\right)$ での到着者数 $\lambda$ $\left(t_{a}\left(t_{d}\right)\right)$ は, $A\left(t_{a}\left(t_{d}\right)\right)$ を時間微分すれば得られる. 以 上の結果定まる均衡状態での待ち行列の時間的推移 は, 図 2 の累積図のように与えられる.

このように本モデルでは，均衡条件式(7)-(13)か ら各時刻の企業の始業時刻選択についての均衡パタ ーンと, それに対応した家計の始業時刻選択パター ン, 及びボトルネックの物理的条件と整合的な家計 の出発時刻選択均衡パターンが定まる.

\section{3. モデルの解析}

前章で定式化したモデルの解析を行い，均衡解と して次の $2 つ の$ 時刻選択均衡パターンが存在しうる ことを明らかにする．1つめは，始業時刻が1点に集 
中しているため, 企業の生産性は高くなるが, 家計 の通勤混雑が最も激しくなる均衡パターンである. 2つめは, 始業時刻が分散しているため, 企業の生 産性は低下寸るが, 家計の通勤混雑が緩和される均 衡パターンである.さらに，ある特定の条件下では， この $2 つ の$ 均衡パターンが同時に成立しうる複数均 衡であることを示す．なお，ここでは紙面の都合上， 均衡解の安定性についての考察は省略する.

\section{（1）パターン 1 : 始業時刻が 1 点に集中する場合}

この均衡パターンでは, 全ての企業が同じ時刻 $\left(t_{w}=0\right)$ に始業するため, 全ての始業時刻選択パター ンのなかで, 企業の生産性は最大となる. 従って, 式(3)で定義した生産関数は,

$$
F(0)=k \frac{N}{L}
$$

である. 始業時刻 $t_{w}=0$ における均衡利潤 $\pi^{*}=0$ であ るので, 企業の時刻選択均衡条件(7)から, 企業か ら家計に支払われる均衡賃金 $W^{*}\left(t_{w}=0\right)$ は，

$$
W^{*}(0)=k \frac{N}{L^{2}}
$$

である，一方，家計にとっては，全ての企業の始業 時刻が集中しているため, ボトルネックでの通勤混 雑は最も激しい状態となる.この均衡パターンで家 計 1 人の負担する均衡交通費用 $C_{T}{ }^{*}\left(t_{w}=0\right)$ は, 条件 (9)を用いることで,

$$
C_{T}^{*}(0)=\frac{\beta N^{2}}{4 \mu^{2}}
$$

と与えられる. 従って, 均衡条件(8)から, この均 衡パターンにおける家計 1 人当たりの均衡効用 $z_{1}$ * は, 次式で与えられる：

$$
z_{1}^{*}=k \frac{N}{L^{2}}-\frac{\beta N^{2}}{4 \mu^{2}}
$$

また，均衡状態に打けるボトルネック出発数と均衡 通勤費用が求まれば，ボトルネックの物理的条件 (14),(15)から, 家計のボトルネック到着パターンが 定まり, 均衡状態におけるボトルネック混雑の時間 的変化は, 図 3 の累積図のように表すことができる

\section{（2）パターン2: 始業時刻が分散する場合}

始業時刻が分散する代表的な均衡パターンとして, 時間 $[0, T]$ の間に, 単位時間当たりに $\bar{m}$ （時刻によ らず一定）の企業が，業務を開始する均衡パターン を解析する，ここで，時刻 $T$ は最も遅く業務を開 始する企業の始業時刻であり, 主体数の保存条件

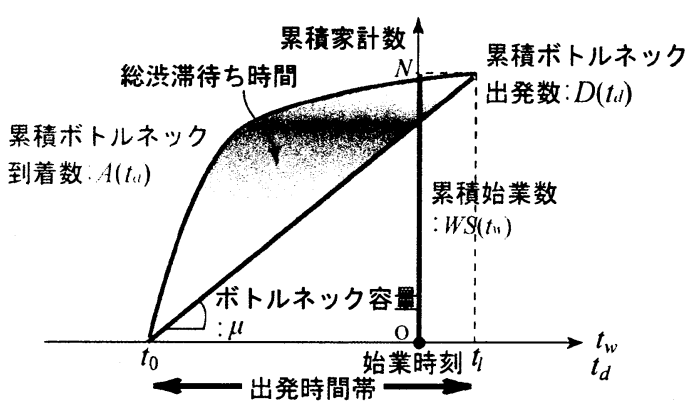

図一3 始業時刻が 1 点に集中する場合

(12)から, $T=N / L \bar{m}$ である. この場合, 企業始業時 刻が連続的に分布するので, 企業の生産性は始業時 間が 1 点に集中する場合よりも低下する.式(3)の 定義から生産関数は, 次式で与えられる：

$$
F\left(t_{w}\right) \equiv k\left(\int_{0}^{t_{w}} \bar{m} d \omega+\int_{t_{w}}^{T}\left\{1-\alpha \cdot\left(\omega-t_{w}\right)\right\} \cdot \bar{m} d \omega\right) .
$$

企業の均衡利潤は $\pi^{*}=0$ であるので均衡条件式(7)か ら, 始業時刻 $t_{w}$ の企業から家計に支払われる均衡 賃金 $W^{*}\left(t_{w}\right)$ は,

$$
W^{*}\left(t_{w^{\prime}}\right)=\frac{k}{L}\left(\int_{0}^{t_{w}} \bar{m} d \omega+\int_{t_{w}}^{T}\left\{1-\alpha \cdot\left(\omega-t_{w^{\prime}}\right)\right\} \cdot \bar{m} d \omega\right)
$$

である. 一方, 始業時刻が分散すると渋滞が緩和さ れるので, 家計が負担する交通費用は削減される.

この場合, 家計の出発時刻選択についての均衡条件 (9)を考慮すると，始業時刻 $\boldsymbol{t}_{w}$ である家計の均衡交 通費用は,

$$
C_{T}^{*}\left(t_{w}\right)=\int_{0}^{T} \frac{d C_{S}(s(w))}{d s} d w
$$

で与えられる (その詳細は, 桑原 》)を参照)。この とき, 企業の始業時刻選択についての均衡条件(7) から, 家計が得る効用 $z_{2}$ は,

$$
z_{2}\left(t_{w}\right)=W^{*}\left(t_{w}\right)-C_{T}^{*}\left(t_{w}\right)
$$

である.この式(24)に，家計の始業時刻選択につい ての均衡条件 :

$$
\frac{\partial z_{2}\left(t_{w}\right)}{\partial t_{w}}=0
$$

を適用すると，単位時間当たりの始業企業数 $\bar{m} か ゙ ，$

$$
\bar{m}=\frac{2 \beta L \mu}{2 \beta L^{2}-\alpha k \mu}
$$

と定まる.これを用いてこの均衡パターンで 1 人当 りの家計が得る均衡効用 $z_{2}^{*}$ を求めることができ 


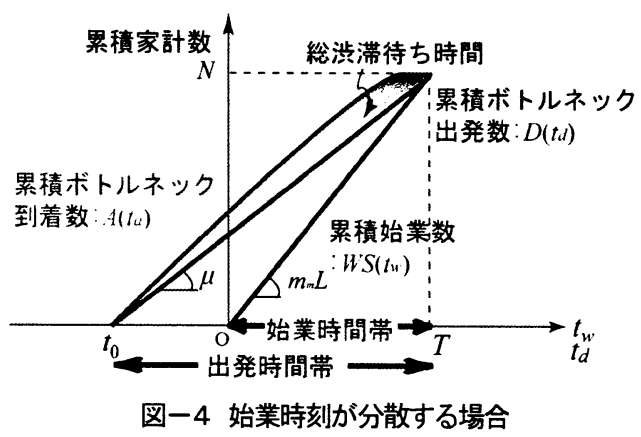

る :

$$
z_{2}^{*}=k \frac{N}{L^{2}}-\beta\left(\frac{L \bar{m}}{\mu}-1\right) \cdot\left(\frac{N}{\bar{m} L}\right)^{2} .
$$

また，均衡パターン 1 と同様に，ボトルネックの物 理的条件(14),(15)から, 家計のボトルネック到着パ ターンを求めることで, 均衡状態におけるボトルネ ック混雑の時間的変化を, 図 4 の累積図で表すこと ができる.

\section{（3）均衡パターンの成立条件と複数均衡パターン}

本稿で扱っている始業時刻の分散施策に関する議 論の本質は, 企業の生産性低下と, 家計の通勤混雑 軽減のトレードオフ関係にある.この点を考慮する と, モデルの解に大きく影響するパラメータは, 次 の 2 つのパラメータであることがわかる. 1 つは, 企業の始業時間差に対する生産性减衰パラメータ $\alpha$ である。もう 1 つは, 正規化した待ち行列時間を指 標とした家計のスケジュール時間に対する時間価値 パラメータ $\beta$ である.そこで, 各均衡パターンの存 在領域を $\alpha-\beta$ 平面上に示すと図 5 のようになる.

図 5 から, 始業時刻が集中する均衡パターン 1 は, 家計のスケジュール時間に対する時間価值パラメー タ $\beta$ が一定の值より小さいとき, すなわち通勤混雑 に対する家計の感じる負効用が小さい条件下でのみ 成立しうるといえる。これは, 均衡パターン 1 は極 めてボトルネック混雑が激しい均衡状態であること を意味する．また，企業の始業時間差に対する生産 性減衰パラメータ $\alpha$ はどんなに大きくても均衡パタ ーン 1 は成立しうる。これは, 均衡パターン 1 が企 業の生産性が最大となる均衡パターンだからである。

一方, 企業の始業時刻が分散する均衡パターン 2 は, 次の $2 つ の$ 条件を満たす共通領域で成立する. その条件とは, 家計の時間価值パラメータ $\beta$ が, 企 業の始業時差に対する生産性減衰パラメータ $\alpha$ より も相対的に大きいという条件, 及び $\alpha$ が一定の值よ りも小さいという条件である. 前者の条件は, 相対

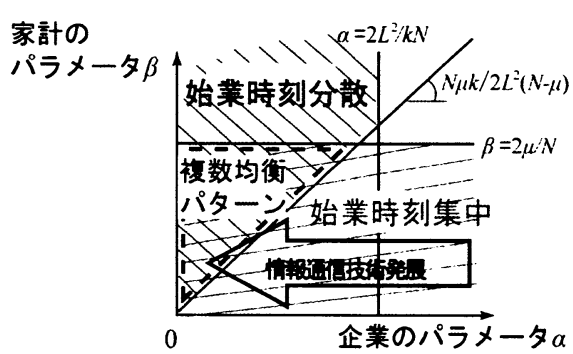

\section{図ー5 各均衡パターンの存在領域}

的に家計の時間価值 $\beta$ が企業の生産性 $\alpha$ よりも優先 する状況下でのみこの均衡パターン 2 が成立するこ とを意味する.これは，この均衡パターン 2 は，企 業の生産性を犠性にして, 家計の通勤混雑を軽減す る均衡バターンだからである，後者の条件は，家計 のパラメータ $\beta$ がどんなに大きくとも，企業のパラ メータ $\alpha$ が一定の值よりも大きい領域では, この均 衡パターンは成立しないことを意味する。なぜなら， 企業の時間価值選好 $\alpha$ が大きい場合には，企業は生 産性を低下させないように始業時間を集中しようと するからである。

図 5 において破線で囲まれた領域では両方の均衡 パターン（複数均衡）が成立することに注意しよう. この領域では, 企業の時間価值 $\alpha$, 家計の時間価値 $\beta$ がどちらも小さく，その中でも相対的に $\beta$ が $\alpha$ よ りも大きい. $\alpha, \beta$ がそれぞれ小さい領域では, 始 業時間が分散しても企業の生産性の低下の影響は小 さく, 始業時刻が集中し通勤混雑が激しくなっても, 家計の感じる負効用は小さくなる. それゆえ, この 領域では企業, 家計の双方の時刻選択について自由 度が広がるために複数の均衡が成立するといえる. ただし, この場合でも, 企業の生産性減衰のパラメ 一夕 $\alpha$ が相対的に家計の時間価值 $\beta$ よりも大きい領 域では, 企業は始業時刻を集中して, 生産性を低下 させないように始業時刻を選択する。

実際に多くの都市で実現している時刻選択パター ンは，本稿のモデルで実現する均衡パターン 1（始 業時刻が集中した均衡パターン）に該当すると考え られる.すなわち，始業時刻が集中しているため多 くの都市で慢性的な通勤啮滞が発生している現状を 考慮すれば，本モデルでは，均衡パターン 1 が実際 の都市の現状を近似しているといえる.

図 5 でどちらの均衡パターンにも属さない右上の 領域では, 解が均衡しないか, あるいは, 均衡パタ ーン 1, 2 以外の他の時刻選択均衡バターンが存在 する可能性もある．ただし，本稿の目的は，社会経 済的に始業時刻は集中した方がよいのか，分散した 方がよいのかを明らかにする点にあるので，それぞ 
れの最も代表的な 2 つの均衡パターン $1 ， 2$ のみを 扱うことにする（他の均衡パターンについては, 付 録 2 参照).

\section{4. 厚生分析}

解析の結果から明らかになった 2 つの均衡パター ンについて，(1) 混雑料金を導入できる場合，(2) 混雑料金が導入できない場合，それぞれについて， どちらの均衡パターンが社会的に望ましいのかを明 らかにする。ここで, 完全競争下で企業の均衡利潤 は $\pi^{*}=0$ となり, 企業の生産性変化による社会的余 剩は，賃金を介して各家計の均衡効用に帰着する. そこで，社会経済的な効率性を評価するには，2つ の均衡パターンの家計の均衡効用を比較すればよい.

\section{（1）混雑料金を導入できる場合}

本モデルの枠組みにおいて, 社会的に First Best （家計の均衡効用が最大）となるのは, 企業の生産 性が最大となる始業時刻が集中した状態で，かつ家 計の通勤混雑が全く発生しない状態である.この状 態を達成する 1 つの方法として, 時間に対して可変 的な混雑料金を賦課する施策が考えられる. より具 体的には，時間によって変わる待ち行列費用相当の 混雑料金を賦課する. その結果, 家計の通勤費用を 変化させずに，家計の通勤混雑を解消できる．その 上で，料金収入を社会的に適切に還元すれば，社会 的余剩は最大となる.ゆえに,このような混雑料金 を導入できる場合には，始業時刻が集中した均衡パ ターン 1 の方が社会的に望ましい.

\section{（2）混雑料金を導入できない場合}

混雑料金を導入できない場合には, 各パターンの 均衡効用(20),(27)を比較して, 均衡効用の大きい方 が社会的に望ましいことになる。式(27)から式(20) の差をとる :

$$
z_{2}{ }^{*}-z_{1}{ }^{*}=\beta N^{2}\left(\frac{\alpha k}{2 \beta L^{2}}-\frac{1}{2 \mu}\right)^{2} \geq 0 .
$$

式(28)において，家計のスケジュール時間遅れに対 する時間価值パラメータ $\beta$ は非負であるので, パラ メータによらず, $z_{2}{ }^{*} \geq z_{1}{ }^{*}$ の関係が成立することが 明らかとなった，従って，混雑料金を導入できない 場合には, 均衡パターン 2 の方が社会的に望ましい. これは，始業時刻が集中した方が企業の生産性は高 くなるが，始業時間を分散させることで，企業の生 産性の低下以上に, 家計の通勤費用を削減できるこ とを意味する.

\section{5. 現実的な通勤混雑緩和施策についての考察}

厚生分析の結果から, 社会的に First Best な通勤 混雑緩和施策は, 始業時間を集中させた状態での混 雑料金導入，すなわち企業の生産性を低下させない ような TDM 施策であることがわかった. しかし， 混雑料金の導入については，時間に対して可変的な 料金徴収システムの技術的問題, 料金収入の適切な 還元をどうするか，そして利用者のコンセンサスが 得られるかといった課題が多く, 実現していないの が現状である。

一方, 企業・職場で利用する情報通信技術の発展 を考慮すると, 始業時間分散による生産性低下の影 響は小さくなると考えられる.この理由は, 情報通 信技術の進展によって, 企業間の取引に対して, 次 の 2 つの効果が期待できるからである. 1 つめは, 企業間でのリふふな face-to-face の会合の必要性を 減少させる効果である．情報通信技術を駆使したバ 一千立市 face-to-face の会合（eg. インターネット ミーティング等）によって, 空間／時間的に離れた 企業間の取引が可能になり，簡単な取引であればリ アルな face-to-face の会合は必要がなくなる. 2 つ は,リアルな face-to-face の会合が必要となる重要 な取引であっても，それを効率化させる効果である. 情報通信技術を利用して, お互いが事前に取引の詳 細内容を把握できれば,リアルな face-to-face に必 要な取引時間も大幅に短縮可能となる.

このように, 企業間でのリアルな face-to-face 取 引の必要性が減少すれば, 企業間での始業時差に起 因する都市全体での生産性低下の影響は小さくなる と考えられる.この効果を本モデルの枠組みで考え ると, 企業の生産関数(3)において, 企業間の始業 時差による生産性減衰パラメータ $\alpha$ が小さくなるこ とを意味する．したがって，情報通信技術の発展に より，図 5 において始業時刻が集中している均衡状 態から, 企業の時閒価值 $\alpha$ が小さい領域，すなわち 複数均衡の領域に状態がシフトする可能性がある.

この場合には，混雑料金が導入できなくとも，次善 の施策として，始業時間を分散させた均衡状態へ誘 導するような TDM 施策（始業時間分散のキャンペ 一ンや補助金交付・規制等）が有効であるといえる.

\section{6. おわりに}

本稿では, 企業の始業時刻選択行動と家計の始 業・出発時刻選択の双方を考慮したモデルを定式化 
し，それを解析することで，始業時刻が集中した均 衡パターンと分散した均衡パターンの2つが存在す ること, さらにはそれらが特定の同一条件下で両方 成立しうること, すなわち複数均衡が存在すること を明らかにした。

次に, この2つの均衡パターンの厚生分析を行い, 混雑料金が導入できる場合には始業時刻が集中した 均衡パターン, 混雑料金が導入できない場合には始 業時刻が分散した均衡パターンが社会経済的に望ま しいことを示した.

最後に, 現実的な通勤混雑緩和についての考察を 行い, 混雑料金が導入できない場合には, 次善策と して, 始業時間を分散させる均衡へ誘導するTDM 施策が有効であるとの結論が得られた。

\section{付録 $1:$ スケジュール費用の関数形}

全ての通勤者の希望到着時刻 $t_{w}$ が同一時刻である との仮定をおいて, ボトルネックモデルを解析した 研究では, スケジュール費用 $C_{S}(s)$ の関数形をスケ ジュール時間 $s$ に対して線形と定義しているもの が多い. しかし, 本稿では, 通勤者の希望到着時刻 （始業時刻） $t_{w}$ が分散する均衡パターンの解析を行 うため, 2次のスケジュール費用関数を仮定した. なぜなら， $C_{s}(s)$ が狭義凸関数であるならば, FIFW 条件 (希望到着時刻 $t_{w}$ の早い者から順にボトルネ ックに流入する条件）を満たす時刻選択パターンが 一意に定まるからである（詳しくはDaganzo ${ }^{8}$ を参 照) . なお, 本稿では2次のスケジュール費用関数 を仮定したが，狭義凸性を満たす関数形であれば， 他の関数形であっても本稿と同様の結果が得られる.

\section{付録 2 : 始業時刻が離散的に分散する均衡パターン}

本稿で定式化した企業と家計の時刻選択均衡モデル の解は，本文中で示した始業時刻が1点に集中するパタ ーンと始業時刻が分散するパターン以外にも, 複数の 均衡パターンが存在することがわかった.ここでは, その複数均衡解の 1 例として, 始業時刻が複数の時刻に 離散的に分散する均衡パターンを示す.

この均衡パターンでは, 時間軸上での $n$ 個の離散 的な時刻 $\mathrm{t}_{\mathrm{w}}=\left\{t_{1}, t_{2}, t_{3}, \cdots, t_{n}\right\}$ に, それぞれ企業数 $\mathbf{m}=\left\{m_{1}, m_{2}, m_{3}, \cdots, m_{n}\right\}$ の企業が業務を開始する.ま た, 始業時刻 $t_{i}, \forall i$ の企業に通勤する家計の出発時 間帯は, その前後の始業時刻 $t_{i-1}, t_{i+1}$ の企業に通勤す る家計出発時間帯とオーバーラップがない状態であ る.この均衡パターンにおいて, 各時刻の始業企業 数 $\mathbf{m}=\left\{m_{1}, m_{2}, m_{3}, \cdots, m_{n}\right\}$ が満たすべき関係を整理

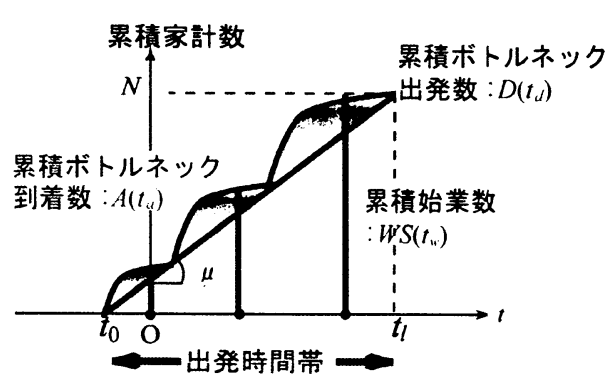

\section{図一6 始業時刻か離散的に分散する均衡パターン}

する.

まず, 生産関数を離散的に考えると, 始業時刻 $t_{w}$ を選択する企業の生産関数は,

$$
F\left(t_{w}\right)=k \frac{N}{L}-\alpha \sum_{i=w}^{n} m_{i} \cdot\left(t_{i}-t_{w}\right)
$$

である. 企業の均衡利潤は $\pi=0$ であるので均衡条件 式(7)から，始業時刻 $t_{w}$ の企業から家計に支払われる 均衡貨金 $W^{*}\left(t_{w}\right)$ は,

$$
W^{*}\left(t_{w}\right)=k \frac{N}{L^{2}}-\frac{\alpha \sum_{i=w}^{n} m_{i} \cdot\left(t_{i}-t_{w}\right)}{L}
$$

である. 次に, 家計の通勤時刻選択に関する条件を 整理する. ある始業時刻 $t_{w}$ の企業に通勤する家計の 通勤時間帯は, その前後の始業時刻に通勤する家計 の通勤時間帯とオーバーラップがないと仮定する：

$$
m_{w} \cdot L=\mu \cdot\left(t_{f}^{w}-t_{l}^{w}\right) .
$$

ここで, $t_{f}^{w}, t_{l}^{w}$ はそれぞれ，始業時刻 $t_{w}$ の企業に， 最も早い時刻に通勤する家計が選択する出発時刻, 及び最も遅い時刻に通勤する家計が選択する出発時 刻である.この仮定の下での家計の均衡交通費用は, 均衡条件式(9)から,

$$
C_{T}^{*}\left(t_{w}\right)=\frac{\beta \cdot\left(L \cdot m_{w}\right)^{2}}{4 \mu^{2}}
$$

と与えられる. さらに, 家計の通勤時間帯にオーバ ーラップがない条件(A3)を始業時間差 $t_{i}-t_{j}$ を用いて 表すと次のようになる：

$$
t_{i}-t_{j}=\frac{L^{2}}{\mu^{2}}\left(\sum_{w=j+1}^{i-1} m_{w}+\frac{m_{j}^{2}+m_{i}^{2}}{4}\right)(i>j) .
$$

また, 各家計の得る均衡効用 $z^{*}$ は始業時刻選択均衡 条件(8):

$$
k \frac{N}{L^{2}}-\frac{\alpha \sum_{i=w}^{n} m_{i} \cdot\left(t_{i}-t_{w}\right)}{L}-\frac{\beta \cdot\left(L m_{w}\right)^{2}}{4 \mu^{2}}=z^{*} \quad \forall m_{w}
$$


を満たす必要がある。これらの条件式(A5),(A6)を同 時に満たす始業企業数 $\mathbf{m}=\left\{m_{1}, m_{2}, m_{3}, \cdots, m_{n}\right\}$ と均 衡効用 $z^{*}$ が均衡解となるが, 始業企業数 $\mathbf{m} か ゙$ 満たす べき関係は再帰的関係にあるため, その特質を明ら かにするには, 数值的な解析が必要となる. この均 衡パターンの例として, 始業時刻が3つに離散的に 分散 $(n=3)$ する均衡パターンのボトルネック累積 図を図6に示す.

この均衡パターンを, 始業時刻が集中する均衡パ ターン 1 と比較した場合の定性的特質は, 連続的に 始業時刻が分散する均衡パターン2と同じである.

すなわち,この均衡パターンにおける企業の生産性 は，始業時刻が分散するため，始業時刻が集中して いる均衡パターン1よりも低下する. 一方, 始業時 刻が離散的に分散することで, 家計の通勤混雑が解 消されるため, 家計の支払う均衡交通費用は, 均衡 パターン1と比較して削减される. 始業時刻 $\mathbf{t}_{\mathbf{w}}$ が 離散的に分散すればするほど, 均衡パターン 1 に対 するこの相対的傾向は顕著になる. 一方, 家計の均 衡効用についても，この均衡パターンで家計が得る 均衡効用は, 始業時刻が集中する均衡パターン1の 均衡効用よりも，大きくなる.

従って, ボトルネック混雑を完全に解消する混雑 料金が導入不可能な場合には,このように始業時刻 が離散的に分散する均衡パターンへ誘導するTDM 施策も有効である.
参考文献

1) Hendrickson,C. and Kocur,G. : Schedule delay and departure time decisions in a deterministic model, Transportation Sciense, Vol.15, pp.62-77,1981.

2) Henderson,J.V. : The economics of staggered work hours, Journal of Urban Economics, Vol.9, pp.349$364,1981$.

3) 文世一：交通混雑の理論と政策【時間・都市空 間・ネットワーク】，東洋経済新報社, 2005 .

4) 奥村誠・小林潔司・田中成興 : 鉄道時差出勤の 社会的便益と導入インセンティブに関する分析, 応用地域学研究,4, pp.63-75,1999.

5) Smith, M.J. : The existence of a time-dependent equilibrium distribution of arrivals at a single bottleneck, Transportation Science, Vol.18, pp.385394, 1984.

6) 井料隆雅 - 吉井稔雄 - 朝倉康夫 : 出発時刻選択 問題の均衡状態に関する数理的分析, 土木学会 論文集, IV-66, pp.105-118, 2005.

7) 桑原雅夫 : 道路交通における出発時刻選択に関 する研究解説, 土木学会論文集, IV-41, pp.7384, 1998.

8) Daganzo, C.F. : The uniqueness of time-dependent equilibrium distribution of arrivals at a single bottleneck, Transportation Science, Vol.19, pp.29$37,1985$.

\section{企業と家計の相互作用を考慮した始業·出発時刻均衡モデル}

佐藤慎太郎・赤松隆

朝の通勤混雑解消のための TDM 施策の 1 つとして, 企業の始業時刻を分散させる時差出勤制の 導入がしばしば議論されてきた。しかし, 始業時刻が分散すると, 企業間の相互取引機会が減少し, 社会的に生産性が低下寸る可能性がある。 そこで，本稿では企業と家計の相互作用を考慮した時刻 選択モデルを構築し, 両者の時刻選択行動から定まる均衡パターンを求めた.この結果, 1)複数の 均衡パターンが存在すること，2)混雑料金を賦課できない場合には始業時刻が分散した均衡パター ンが望ましいこと，3)混雑料金を賦課できる場合には始業時刻が集中する均衡パターンが望ましい こと，が明らかになった.

\section{A Simultaneous Equilibrium Model of Work Start Time \& Departure Time Choices with Bottleneck Congestion}

By Shintaro SATO and Takashi AKAMATSU

Staggered work hours in a city have been introduced to mitigate commuting congestion. However, it may lead to decline in mutual dealing chances between firms, and there is a possibility that total productivity in the city decreases. In this paper, we construct a model in which work start time choices by firms and departure time choices by commuters determine total productivity and commuting congestion in the city. Analyzing of the model, we show that 1) multiple equilibrium patterns of time choices can occur, 2) the equilibrium pattern where work start time is staggered is desirable if congestion tax cannot be levied, and 3) the equilibrium pattem where work start time is concentrated is desirable if congestion tax can be levied. 